\title{
Bir Üniversite Hastanesinde Çalışan Hemşirelerin Hastanede Kullanılan Hemşirelik Bakım Planını İyileştirme Konusundaki Görüş ve Önerileri: Karma Modelde Bir Çalışma
} $\infty$

\author{
ilkay YURTSEVER ${ }^{1}$, Şerife KARAGÖZOĞLU²
}

\section{ÖZ}

Amaç: Çalışma, bir üniversite hastanesinin kliniklerinde kullanılan hemşirelik bakım planını iyileştirmeye yönelik görüş ve önerilerin belirlenmesi amacıyla yapılmıştır.

Gereç ve Yöntem: Araştırma, nicel-nitel araştırma yöntemlerinin birlikte kullanıldığı karma modelde tasarlanmış olup, tanımlayıcı niteliktedir. Araştırmanın örneklemini, bir üniversite hastanesinde bakım planı ile çalışan 226 hemşire oluşturmuştur. Araştırmanın nitel boyutunda 3 ayrı grupla odak grup görüşmesi yapılmıştır. Nicel boyutunda ise odak grup görüşmeleri ve literatür doğrultusunda oluşturulan anket formları bakım planı ile çalışan hemşirelere uygulanmıştır. Nitel verilerin değerlendirilmesinde içerik analizi, nicel verilerin değerlendirmesinde ise tanımlayıcı istatistiksel yöntemler (sayı, yüzde) kullanılmıştır.

Bulgular: Araştırmanın nitel boyutunda odak grup görüşmesine katılan hemşireler genel olarak hemşirelik bakım planı ile çalışmanın yararlı olduğunu ifade etmiş, ancak bakım planı kullanımının birçok faktörün etkisiyle yeterince etkin yapılamadığını bildirmiştir. Araştırmanın nicel boyutunda ise; katılımcıların \%70.8'i çalıştıkları kliniklerde bakım planlarının etkin kullanılmadığını belirtmiştir.

Sonuç: Çalışmanın uygulandığı üniversite hastanesinde hemşirelerin hemşirelik bakım planlarını etkin olarak kullanamadıkları ve buna birçok faktörün neden olduğu tespit edilmiştir. Etkili, hedefe dönük ve bireyselleştirilmiş bakım planının hayata geçirilmesini sağlamada, olumsuz kurumsal faktörlerin ortadan kaldırılması ve hemşirelerin iyileştirmeye yönelik çözüm önerilerinin dikkate alınması yararılı olacaktır.

Anahtar kelimeler: Hemşirelik, hemşirelik bakım planı, iyileştirme

\begin{abstract}
The Views and Suggestions of Nurses Working at a University Hospital on Improving the Nursing Care Plan Used in the Hospital: A Mixed-Model Study

Aim: The study was conducted with the aim of determining views and suggestions for improving the nursing care plan used in the clinics of a university hospital.

Material and Methods: The research design was mixed method using both quantitative and qualitative methods. The sample of the study consisted of 226 nurses working with the care plan in a university hospital. Focus group discussions were conducted with three different groups in the qualitative dimension of the study. In the quantitative dimension, questionnaire forms created in line with the focus group interviews and the literature were applied to the nurses working with the care plan. Content analysis was used for the evaluation of qualitative data whilst descriptive statistical methods (number, percentage) were employed for the analysis of quantitative data.

Results: In the qualitative part of the research, the nurses particpating in the focus group discussions stated that working with a nursing care plan was generally beneficial, but reported that the use of care plan could not be done efficiently due to many factors. In the quantitative part of the research, $70.8 \%$ of participants reported that the care plans were not used effectively in the clinics they worked.

Conclusion: It was found that nurses failed to use nursing care plans effectively at the university hospital where the study was conducted and this was caused by many factors. In order to ensure the use of an effective, target-oriented and individualized care plan, it would be beneficial to eliminate negative institutional factors and consider the nurses' suggestions for improvement.

Keywords: Improvement, nursing, nursing care plan
\end{abstract}

${ }^{1}$ Hemşire, Cumhuriyet Üniversitesi Sağlık Hizmetleri Uygulama ve Araştırma Hastanesi, Hemovijilans Birimi, Sivas, Türkiye, E-mail: ilkayyurtsever@ @hotmail.com, Tel: 0 532 6882766, ORCID: 0000-0001-5460-6137

2Prof. Dr., Cumhuriyet Üniversitesi Sağlık Bilimleri Fakültesi Hemşirelik Bölümü, Sivas, Türkiye, E-mail: serifekaragozoglu@gmail.com, Tel: 0 532 7427059, ORCID: 00000002-9558-0786

Geliş Tarihi: 21 Kasım 2019, Kabul Tarihi: 19 Haziran 2020

*Bu çalışma, 02-05 Mayıs 2018 tarihlerinde Burdur Mehmet Akif Ersoy Üniversitesi'nde gerçekleştirilen 1. Uluslararası Sağlık Bilimleri ve Yaşam kongresinde sözel bildiri olarak sunulmuştur.

Atıf/Citation: Yurtsever i, Karagözoğlu Ş. Bir Üniversite Hastanesinde Çalışan Hemşirelerin Hastanede Kullanılan Hemşirelik Bakım Planını İyileştirme Konusundaki Görüş ve Önerileri: Karma Modelde Bir Çalışma. Hacettepe Üniversitesi Hemşirelik Fakültesi Dergisi 2020; 7(3): 215-225. DOI: 10.31125/hunhemsire.834055 


\section{GíRiş}

Hemşirelik süreci sağlıklı/hasta bireyin sağlık bakım gereksinimlerinin tanımlanması ve bireye özgü bakım verilmesinde kullanılan bilimsel bir yaklaşım ve sistematik bir yöntemdir1,2. Dünya Sağlık Örgütü (DSÖ) hemşirelik sürecini, hemşirelik bakımında bilimsel problem çözümleme yönteminin sistemli bir biçimde kullanılması olarak tanımlamıştır ${ }^{3}$. Hemşirelik uygulamalarının temelini oluşturan hemşirelik süreci, bireyin ve ailenin bakım gereksinimlerinin belirlenmesi, gerekli hemşirelik girişimlerinin planlanması, uygulanması ve sonucunun değerlendirilmesi aşamalarından oluşur ${ }^{1,4}$. Hemşirelik süreci kavramı ilk kez Lydia Hall tarafından, 1955 yılında bir makalede kullanılmış, daha sonra Johnson (1959), Orlando (1961) ve Wiedenbach (1963) tarafından bir kavram olarak ele alınmıştır. 1967'de Yura ve Walsh hemşirelik sürecinin dört aşamasını belirlemişlerdir ${ }^{2}$. Bu tarihten sonra bazı lider hemşireler ve hemşirelik kuruluşları, hemşirelik süreci aşamalarını benzer yaklaşımla, fakat farklı adımlarla ele almışlardır ${ }^{4}$.

Birçok sanat, meslek ve disiplinde olduğu gibi hemşirelik de hem mesleki gelişmeleri hem de artan toplumsal beklentileri karşılayabilmek için vazgeçilmez bir ölçüt olan bilimselliği temel almaktadır ${ }^{4}$. Hemşireler bakımın sistematiği için bilimsel bir araç olarak hemşirelik sürecini kullanır ${ }^{4}$. Hemşirelik bakımında hemşirelik sürecinin kullanılmasının birçok yararı vardır. Hemşirelik süreci kullanılarak planlanan bakım; veri toplama, plan yapma, uygulama ve sonuçları değerlendirme yoluyla birey merkezli yaklaşımı ve bilgiye dayalı uygulamaları esas alarak, kaliteli hizmet sunumunu sağlar ${ }^{1,4-6}$. Hasta bakımının görünürlüğünü, kanıtlanabilirliğini $\operatorname{arttırır}^{1,5,6}$. Hemşirelik süreci, eleştirel düşünmenin ışığında hastanın sorunlarını sistematik bir biçimde saptama, bunların çözümü için plan yapma, planı uygulamaya koyma, yapılan planı tanımlama ve sorunların çözümündeki etkisinin derecesini değerlendirmeyi sağlayarak, hemşirenin karar verme, araştırma, savunma, değişim, liderlik, yardım etme ve eğitim gibi rollerini kullanmasına fırsat verir5,7. Bakımın kayıt edilmesini kolaylaştırır, hastaya verilen bakımın daha objektif olarak değerlendirilmesini sağlar ${ }^{1,5,6}$.

Dünyada birçok ülkede profesyonel hemşirelik bakımının sunumunda hemşirelik süreci yaklaşımı kullanılmaktadır. Ülkemizde ise Hemşirelik Kanunu (2007) ile hemşirelerin hemşirelik süreci doğrultusunda birey ve toplumun sağlık gereksinimlerini belirleme, hemşirelik bakımını planlama, uygulama ve değerlendirmesi, diğer bir anlamda bilimsel problem çözme yöntemi olan hemşirelik süreci ile bakım vermesi kanunlaştırılmıştır ${ }^{8}$. Öte yandan hemşirelik süreci ile çalışmanın Sağlık Hizmet Kalite Standartları Hasta Bakım Hizmetleri' nde zorunlu bir uygulama olması birçok hastanede hemşirelik süreci yaklaşımının klinik uygulamalarda kullanımının yaygınlaşmasını sağlayacak birtakım girişimlerin hayata geçirilmesine neden olmuştur ${ }^{9}$. Hemşirelik sürecinin kullanımında; hemşirelik mesleğine ve bakım kalitesine olan olumlu katkıları ve yasal düzenlemelerin etkisiyle artış olmuştur ancak hemşirelerin çeşitli nedenlerden dolayı (Klinik uygulama alanlarında kısıtlı zaman, fazla iş yükü, personel ve malzeme yetersizliği, bilgi ve eğitim eksikliği, hemşireler tarafından iş yükü olarak görülmesi) uygulamada hemşirelik sürecini yeterince kullanmadığı da bilinen bir gerçektir ${ }^{10}$. Nitekim bu konuda yapılan araştırmalar, hemşirelik sürecinin kullanımı ile ilgili güçlüklerin (Yüksek oranda iş yükü, hasta sayısının fazla olması, sistem/alt yapı eksikliği, eleman yetersizliği, zaman yetersizliği, yeterli bilgi ve donanıma sahip olmama, bakım planı ile çalışmayı iş yükü olarak görme) yaşandığını ortaya koymakta bu güçlüklere karşın, kliniklerde hemşirelik sürecinin uygulanabilirliğini sağlanmaya yönelik öneriler sunmaktadır ${ }^{10-21}$. Bu kapsamda ele alındığında bu çalışmada bir üniversite hastanesinde, hemşirelik süreci doğrultusunda oluşturulan bakım planlarının uygulanmasına yönelik güçlüklerin tespit edilmesi ve mevcut uygulamanın iyileştirilmesine yönelik görüş ve önerilerin belirlenmesi hedeflenmiştir.

\section{Araştırmanın Amacı}

Çalışmadan elde edilecek sonuçlar ile hemşirelik süreci yaklaşımıyla hazırlanan bakım planlarının klinik ortamlarda etkin kullanımını engelleyen faktörlerin açığa çıkarılmasını sağlamaktır.

\section{GEREÇ ve YÖNTEM}

\section{Araştırmanın Türü}

Araştırma nicel-nitel araştırma yöntemlerinin birlikte kullanıldığı karma modelde tasarlanmış olup, tanımlayıcı niteliktedir. Çalışma iki aşamada yürütülmüştür. Birinci aşamada odak grup görüşmeleri yapılmış, ikinci aşamada odak grup görüşmeleri ve ilgili literatür1,6,10-14,16-19 doğrultusunda oluşturulan anket formu örneklem grubuna uygulanmıştır.

\section{Araştırma Evren ve Örneklemi}

Çalışmanın gerçekleştirildiği üniversite hastanesinde, hemşirelik bakım planının kullanılmasına ilişkin çalışmalar 2013 yılı Nisan ayı itibariyle hastane başhemşireliği tarafından başlatılmıştır. Başhemşirelik tarafından Kuzey Amerika Hemşirelik Tanılama Birliği (NANDA) tanıları incelerek bu tanılardan 89 tanesini içeren standart bakım planları oluşturulmuştur. Oluşturulan standart bakım planları bilgisayarda aynı formatta yazılmış ve Hastane Kalite Birimi ile iletişime geçilerek form doküman numarası alınmıştır. Formlar tüm birimlerde ünite bilgisayarlarına "Ortak klasör" adıyla ana ekrana tanımlanmıştır. Hemşireler hastanın tanımlayıcı özelliklerine takip edecekleri (tanıya göre düzenlenmiş) planı bilgisayardan kâğıt çıktısı şeklinde alarak doldurmakta ve dosyalamaktadır.

Her hemşirelik tanısı için ayrı bir form düzenlenmiştir. Formlar hastada bulunan tanımlayıcı özellikleri yazmak için ayrılmış bir alan içermektedir. Aynı form üzerinde hemşirelik tanısına yönelik yapılabilecek tüm hemşirelik uygulamaları numara verilerek sıralanmıştır. Hemşire formun hemşirelik uygulamaları alanına yaptığı uygulamanın numarasını sayı olarak her şift kaydetmektedir. Hasta bakım süreci hasta yatışı ile başlamakta, değişen durumlarda yeni tanılar için yeni çıktı alınmaktadır. Oluşturulan bakım planları hastane genelinde uygulanmaya başladıktan sonra hemşireler tarafından bakım planı ile çalışmada yaşanan zorluklar ifade 
edilmeye ve kullanılan formatın daha uygun hale getirilmesi konusunda öneriler sunulmaya başlanmıştır.

\section{Birinci Aşama}

Nitel araştırmanın örneklemi amaçlı örnekleme yöntemlerinden benzeşik (Homojen) örnekleme yöntemi ile seçilmiştir. Hastanede halen kullanılmakta olan bakım planı formatının geliştirilmesine katkı sağlayan 5 hemşire birinci görüşme grubunu, bakım planlarının düzenli olarak kullanıldığı dahili ve cerrahi kliniklerin sorumluluğunu yürüten 10 hemşire ikinci görüşme grubunu, bakım planlarının düzenli olarak kullanıldığı dahili ve cerrahi kliniklerde vardiyada görev yapan 10 hemşire üçüncü görüşme grubunu oluşturmuştur. 3 ayrı grupla görüşme yapılmasının amacı, kurumda hemşirelik bakım planını oluşturan, klinik yöneticisi olarak görev yapan ve bakım planını uygulayan hemşireler açısından farklı bakış açılarıyla kullanılan hemşirelik bakım planına yönelik sorunları ve çözüm önerilerini tespit etmektir.

\section{İkinci Aşama}

Nicel araştırmanın evrenini, bir üniversite hastanesinde 1 Şubat- 31 Temmuz 2017 tarihleri arasında hemşire olarak görev yapan ve hemşirelik süreci doğrultusunda bakım planı ile çalışan 304 hemşire oluşturmuştur. Hastanede hemşirelik bakım planı sadece yatan hastalara uygulanmaktadır. Odak grup görüşmeleri sonrasında oluşturulan anket formunun ön uygulamasına dahil edilen 15 hemşire, araştırmanın yapıldığı tarihte izinli ya da raporlu olan 35 hemşire, veri toplama formunda hata tespit edilen 6 hemşire, araştırmaya katılmayı kabul etmeyen 15 hemşire ve hemşire dışında görev yapan 7 ebe araştırma kapsamı dışında bırakılmış ve 226 hemşire örnekleme alınmıştır.

\section{Verilerin Toplanması}

Araştırmanın verileri, odak grup görüşmeleri ve literatür ${ }^{1,6,10-14,16-19}$ doğrultusunda oluşturulan anket formu ile toplanmıştır.

\section{Veri Toplama Araçları}

\section{Anket Formu}

Çalışmanın ikinci aşamasında kullanılan anket formunda sorular üç bölüm halinde oluşturulmuştur. Formun birinci bölümünde, hemşirelerin bazı bireysel ve mesleki tanıtıcı özellikleri (17 soru), ikinci bölümünde bakım planı sürecinin kullanması sırasında yaşanan güçlükleri belirlemeye yönelik (14 soru) çoktan seçmeli sorular sorulmuştur. Üçüncü bölümünde ise odak grup görüşmeleri sonucunda belirlenen bakım planı sürecinin kullanması sırasında yaşanan güçlüklere yönelik çözüm önerilerini sıralanmış ve kendilerine uygun olan önerileri işaretlemeleri istenmiştir.

\section{Veri Toplama Araçlarının Uygulanması}

Birinci Aşama: Nitel Veri Toplama Araçlarının Uygulanması

1 Şubat- 31 Mart 2017 tarihleri arasında üç ayrı grupla her biri 60-75 dakika süren ikişer odak grup görüşmesi yapılmıştır. Görüşme günleri grupta bulunan hemşirelerin çalışma listeleri de göz önüne alınarak planlanmıştır. Gruplara ayrılan hemşirelere araştırmanın tarihi, saati ve yeri hakkında bilgi verilmiştir. Belirlenen tarihler ve saatlerde $U$ oturma düzeninin oluşturulduğu hastane kalite birimi toplantı salonunda, bir moderatör ve bir raportör ile görüşmeler gerçekleştirilmiştir. Odak grup görüşmeleri, birbirinden ayrı üç grupla gerçekleştirilmiş, katılımcılardan izin alınarak video kamera ve ses kayıt cihazı kullanılarak kayıt altına alınmıştır. Görüşmeler için yapılandırılmış 10 açık uçlu soru hazırlanmış ve her gruba aynı sorular sorulmuştur. Görüşmelerde mevcut bakım planlarının geliştirilme süreci, standart bakım planının farklı kliniklerde uygulanabilirliği ve etkinliği, bakım planı ile çalışmanın getirdiği avantajlar, dezavantajlar ele alınmıştır.

ikinci aşama: Nicel Veri Toplama Araçlarının Uygulanması Odak grup görüşmelerinden elde edilen veriler ve ilgili literatür1,6,10-14,16-19 kapsamında oluşturulan anket formu, 1 Nisan- 31 Temmuz 2017 tarihleri arasında bakım planı ile çalışan ve araştırmaya katılmayı kabul eden tüm hemşirelere uygulanmıştır. Araştırmaya katılan hemşirelere çalışma hakkında sözel bilgi verilip yazılı onamları alınmıştır. Veriler, hemşireler ile yüz yüze görüşme yöntemiyle, ortalama 15 dakika görüşülerek elde edilmiştir.

\section{Araştırmanın Etik Boyutu}

Araştırmanın uygulanabilmesi için araştırmanın yapılacağı hastanenin yönetiminden yazılı izin ve Cumhuriyet Üniversitesi Girişimsel Olmayan Klinik Araştırmalar Etik Kurulu'ndan onam alınmıştır (2017- 01/24). Araştırmaya katılan tüm hemşirelere bilgilendirilmiş onam formu okunarak, sözlü ve yazılı izinleri alınmıştır.

\section{Verilerin Analizi}

\section{Birinci Aşama}

\section{Nitel Verilerin Analizi}

Odak grup görüşmelerinde kayıt altına alınan nitel veriler araştırmacılar tarafından içerik analizi ile değerlendirilmiştir. Kayıtlar yazılı ortama aktarılarak, benzer ifadeler alt alta eklenmiş, özetleyici içerik analizi yöntemi kullanılarak özetlenmiştir. Elde edilen veriler üzerinde yapılan inceleme sonucunda uzman görüşü alınarak temalar belirlenmiştir. Bu uzmanların hepsi Hemşirelik Esasları alanında doktora yapmış olup, üçü akademik alanda, üçü ise klinik alanda görev yapmaktadır. Veriler üç anahtar tema (Engeller, Öneriler, Yararlar) altında toplanmıştır. Odak grup görüşmelerinden elde edilen veriler, anket formunun oluşturulması sürecinde kullanılmıştır.

İkinci aşama

\section{Nicel Verilerin Analizi}

Verilerin analizinde SPSS 16 versiyonu kullanılmıştır. Çalışma verileri değerlendirilirken tanımlayıcı istatistiksel yöntemler (sayı, yüzde) kullanılmıştır.

\section{Araştırmanın Sınırlılıkları}

Araştırma, verilerin toplandığı üniversite hastanesinde görev yapmakta olan hemşirelerle sınırlıdır. Bu nedenle sonuçlar yorumlanırken bu sınırlılığın dikkate alınması gerekmektedir. Bu çalışmanın bir sınılıılığı da araştırmaya katılan hemşirelerin kendi bildirimine dayanmasıdır. Dolayısıyla sonuçlar, araştırma kapsamına alınan hemşirelerin vermiş oldukları yanıtlarla sınırlıdır.

BULGULAR

Birinci Aşama

Odak grup görüşmesine katılan hemşirelerin bazı mesleki özellikleri Tablo 1'de belirtilmiştir. 
Hemşireler ile yapılan görüşmeler sonunda üç ana tema belirlenmiştir: (1) Yararlar: Hemşirelik bakım planı ve yararlarına ilişkin görüşler, (2) Engeller: Hemşirelik bakım planı eğitimi ve hastanede kullanılan hemşirelik bakım planına ilişkin görüşler, (3) Öneriler: Hastanede kullanılan hemşirelik bakım planının daha etkin hale getirilmesine ilişkin görüşler.

\section{Tema 1. Bakım Planı Uygulamasının Yararları}

Gruplarda yer alan katılımcılar hemşirelik süreci doğrultusunda hemşirelik bakım planı ile çalışmanın yararlı ve hemşireliğin olmazsa olmaz çalışma yöntemi olduğunu, hemşirelik bakımını görünür kıldığını, bilgi ve deneyimi yansıtan bir evrak niteliğinde olduğunu, çalışanlara rehberlik ettiğini, hastaya bireysel bakım vermeyi sağladığını, çalışanı yasal anlamda korumak için kullanılması gereken zorunlu bir yöntem olduğunu, hastaya ancak bu yöntem ile bütüncül bir bakım verilebileceğini ifade etmişlerdir. Bu kapsamda katılımcıların konuya ilişkin ifadeleri şöyledir:

"Bakım planının olması bakımın sistematik olmasını sağlıyor, bakımın atlanmasını önlüyor, hastanın öncelikli sorunlarını fark etmeyi sağlıyor, olması gerekir, geç kalınmış. Çok form dolduruluyor ama hemşirelik bakımını gösteren aslında bakım planıdır, hemşire sorunları ilk fark eder ama bu görünmüyordu. Olmazsa olmaz. Bakım planı hemşirelik hizmetlerinin görünür olmasını sağlıyor, aynı zamanda yasal dayanaktır." (K1, Yüksek Lisans, 33 yaş, Birinci Görüşme Grubu)

"Hemşirelikte bakımın sanata dönüştürülmesidir..." (K2, Lisans, 43 yaş, ikinci Görüşme Grubu)

"Hekim nasıl anamnez alıp tanı koyuyorsa, ben de anamnez alıp, hemşirelik tanısı koyabilmeliyim. Kâğıt işi gibi algılanıyor, bu kadar elemanla bunu yapmak zor ama belli bir aşamaya gelindiğinde daha iyi olacağını, kendiliğinden yapılacağını, bu kurumda çalışan hemşirelerin bu iş için avantaj olduğunu düşünüyorum. Zaman olarak 40 hastaya birer tanı koymayı yapabiliyoruz. Hasta açısından yapmamız gereken, zaman alan çok işler var. Olmalı ama eklenecek şeyler var." (K1, Lisans, 41 yaş, ikinci Görüşme Grubu) "Bakım planı etkin kullanıldığında hemşirenin pusulasıdır. Ne yaptı̆̆ımızı ne ettiğimizi ne yapacağımızı gösterir. Bunun yanında hemşirelik mesleğinin sadece enjeksiyon yapmadan ya da tansiyon ölçmeden ibaret olmadığını gösteren resmi bir evraktır. Etkin kullanıldığında bizim mesleğimiz eşittir bakım planı diyebiliriz." (K3, Lisans, 31 yaş, Üçüncü Görüşme Grubu)

\section{Tema 2. Bakım Planının Uygulanmasında Yaşanan Engeller}

Katılımcılar genel olarak; gerekliliğine inanmakla birlikte bakım planını isteksiz ve zorunlu olarak yaptıklarını, yapılan bakım planın etkin olmadığını ve bu duruma birçok faktörün neden olduğunu bildirmiştir. Katılımcılar bakım planının uygulamasında birçok sorunla karşılaştıklarını belirtmiş ve bu sorunları şu şekilde sıralamıştır: Kliniklerde hemşire sayısının yetersiz olması, bakım verilen hasta sayısının fazla olması, zaman yetersizliği, bakım planı ile çalışmaya başlamadan önce tüm uygulayıcıların kapsamlı ve sistematik bir eğitim sürecinden geçmemesi, basılı formların dosyalarda çok yer kaplaması, kâğıt israfının yaşanması, doldurulması gereken çok fazla formun bulunması, bakım kaydı ve kabul formundaki bazı bilgilerin birden çok yere yazılması gerekliliği, dosyalama sisteminin standart ve uygun olmaması, kliniklere özgü tanılamanın yapılamaması, yetersiz veri toplanması, hastanın gereksinimlerine yanıt verecek bireyselleştirilmiş bakım planının uygulanamaması, öğrencilik döneminde yaşanılan olumsuz deneyimler ve iş yükü olarak görülmesi. Bu kapsamda katılımcıların konuya ilişkin ifadeleri şöyledir:

"Bakım planının yapılması gerekiyor ama öğrencilikte sürekli yapıldığı için çalışırken insan sıkılabiliyor. Meslek hayatında 2-3 değil, 15 hastaya bakım planı yapıyoruz. Bu nedenle bakım planı yapmak zaman kaybı gibi gelebiliyor." (K4, Yüksek Lisans, 43 yaş, Birinci Görüşme Grubu)

"itaki formunu kullanmak zorunlu deniyor, bakım planında travma riski de var. Aynı formların sürekli doldurulması gereksiz. Örneğin dekübit formu ve bakım planındaki yara bakımının birlikte doldurulması, kabul formundaki bazı bilgilerin birçok yere yazılması gereksiz iş yükü." (K3, Lisans, 41 yaş, Birinci Görüşme Grubu)

"Teknoloji çağındayız, yeni nesil neden elden dolduruyoruz diyor. Neden bilgisayar olmuyor. Örneğin dijital... Bakım planı dijital olmadığı için daha az tanı konulabiliyor. Hasta odalarına bir dijital neden yapıştırılmıyor bu noktaya gelmesinde çok büyük emekler var. Daha farklı olabilirdi en başta online olacaktı ama sistemsel paket yüzünden yapamadık." (K1, Yüksek Lisans, 33 yaş, Birinci Görüşme Grubu)

"Dosyalar açısından sıkıntı var. Delgeçle hepsini tek tek delmek zaman alıyor. Bunu muhafaza edecek güzel bir dosya olması gerekiyor ama kullanıma uygun dosya olmadığı için hemşire açısından sıkıntı. Uygun dosyalama sisteminde sorun oluyor." (K5, Lisans, 33 yaş, ikinci Görüşme Grubu)

"Ben klinikte ve hastanede veri toplama konusunda eksiklik olduğunu düşünüyorum. Bu konuda eğitim alabiliriz diye düşünüyorum. Veri olmadan bakım planının anlamı olmadığını düşünüyorum." (K5, Lisans, 31 yaş, Üçüncü Görüşme Grubu)

"Hastaya faydası olmuyor, zaten uygulamaları yapıyoruz, kaydediyoruz. Yaptık mı yaptık... Hastaya da bana kattığı bir şey olmadığından bir dezavantaj olarak görüyorum. Vakit kaybına neden oluyor." (K3, Lisans, 31 yaş, Üçüncü Görüşme Grubu) 
Tablo 1. Odak Grup Görüşmesi Yapılan Grupların Bazı Mesleki Özelliklerine Göre Dağılımı

\begin{tabular}{|c|c|c|c|c|c|c|}
\hline \multicolumn{7}{|c|}{ GÖRÜŞME GRUPLARI } \\
\hline \multirow[t]{2}{*}{ Özellikler } & \multicolumn{2}{|c|}{ Bakım Planını Geliştiren Grup n=5 } & \multicolumn{2}{|c|}{$\begin{array}{c}\text { Klinik Sorumlusu Grubu } \\
n=10\end{array}$} & \multicolumn{2}{|c|}{ Mesai / Vardiya Grubu n=10 } \\
\hline & Sayı & $\%$ & Sayı & $\%$ & Sayı & $\%$ \\
\hline \multicolumn{7}{|l|}{ Yaş } \\
\hline $19-25$ yaş & - & - & - & - & 1 & 10 \\
\hline $26-32$ yaş & - & - & - & - & 6 & 60 \\
\hline 33-39 yaş & 1 & 20 & 5 & 50 & 3 & 30 \\
\hline 40 yaş ve üzeri & 4 & 80 & 5 & 50 & - & 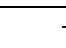 \\
\hline \multicolumn{7}{|l|}{ Eğitim Durumu } \\
\hline Lisans Mezunu & 3 & 60 & 9 & 90 & 10 & 100 \\
\hline $\begin{array}{l}\text { Lisansüstü } \\
\text { Mezunu }\end{array}$ & 2 & 40 & 1 & 10 & - & 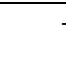 \\
\hline \multicolumn{7}{|l|}{ Çalışılan Klinik } \\
\hline Cerrahi Klinik & 2 & 40 & 2 & 20 & 4 & 40 \\
\hline Dahili Klinik & 2 & 40 & 5 & 50 & 5 & 50 \\
\hline Acil Servis & - & - & 1 & 10 & - & 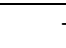 \\
\hline Yoğun Bakım & - & - & 2 & 20 & 1 & 10 \\
\hline Başhemşirelik & 1 & 20 & - & - & - & 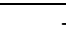 \\
\hline \multicolumn{7}{|l|}{ Çalışma Süresi } \\
\hline 5 yıl ve altı & - & - & - & - & 4 & 40 \\
\hline 6-10 yıl & - & - & - & - & 4 & 40 \\
\hline $11-15$ yıl & 1 & 20 & 5 & 50 & 2 & 20 \\
\hline 16 yıl ve üzeri & 4 & 80 & 5 & 50 & - & . \\
\hline Toplam & 5 & 100 & 10 & 100 & 10 & 100 \\
\hline
\end{tabular}


Tema 3. Hastanede Kullanılan Hemşirelik Bakım Planının Daha Etkin Hale Getirilmesine ilişkin Öneriler

Katılımcılar genel olarak kurumda kullanılmakta olan hemşirelik bakım planının geliştirilmesi ve daha etkin hale getirilmesine yönelik şu önerilerde bulunmuşlardır:

Format ile ilgili olarak; bakım planının bilimsel dayanaklar ile yeniden yapılandırılması, farklı birimlerin kendilerine özel tanılar koyabilmesi ve bu konuda alanında uzman kişilerden görüş alınması, basılı formda veri kaydı, bakımın değerlendirmesi ve imza için yeterli, uygun alanların bulunması, değerlendirme alanının çek atılabilir şekilde düzenlenmesi, kurumsal olarak; çalışan sayısının artırılması, bakım planının bilgisayar tabanlı kayıt sistemi çerçevesinde yeniden yapılandırılması ve bunun üst yönetim tarafından desteklenmesi, tüm bakım kayıtlarının bakım planı kapsamında yer alması, bakım planının performans ödemelerine yansıtılması, yöneticiler tarafından kurumda çalışanların motivasyonunu artıracak girişimlerin hayata geçirilmesi ve çalışma koşullarının iyileştirilmesi, eğitimle ilgili olarak; bakım planı eğitimlerinin yıllık eğitim hedeflerine konulması, kurumda verilecek eğitimlerin kliniklere özel olarak, periyodik aralıklarla yapılması ve dijital kayıt yapan hastanelerin ziyaret edilmesi. Katılımcıların konuya ilişkin ifadeleri aşağıda verilmiştir:

"Bakım planı dijital olsa daha iyi olur. Bazı hastanelerde bunun yapıldığı sistemler varmış. Bir çek atılıp gidilmesi çok büyük kolaylık. Bakım planı hastane kalite sistem denetiminde 25 puan getiren bir uygulama. Bu nedenle kurum; bu uygulamanın daha etkin hale getirilmesi konusunda gerekli her tür katkı ve desteği sağlamalı." (K1, Yüksek Lisans, 33 yaş, Birinci Görüşme Grubu)

"Hem hemşire gözlem kağıdına yazıp hem de bakım planı yapıyoruz. Her ikisinde de yazmak zaman alıyor. Ekip, hemşire gözleme tekrar yazmayalım diyor. Ağız, göz bakımı hem gözlemde var hem de bakım planlarında var. Örneğin beslenme her ikisinde de var. Gözlem hemşirenin sadece not düşeceği yer olsun. Bakımlar bakım planında olsun. Tek birine not düşülmesi gerekir." (K1, Lisans, 41 yaş, ikinci Görüşme Grubu)

"Mevcut bakım planları servislere özel değil. Bölümlerde birimlere özel çalışmalar yapılabilir. Örneğin; Psikiyatri, Göğüs Hastalıkları, Kadın Doğum alanlarında özel çalışmalar olabilir. Genel bir çalışma yapılmış; şimdi de her bölüme özel bakım planı çalışmaları yapılabilir. Örneğin, Gögüs Hastalıklarına yönelik tanılar yetersiz, buna yönelik çalışılması gerekir." (K9, Lisans, 39 yaş, Üçüncü Görüşme Grubu)

\section{İkinci Aşama}

Araştırma kapsamına alınan hemşirelerin yaş ortalamasının $30 \pm 4.23$ (min: 26, maks: 42) olduğu, \%77.9'sinin kadınlardan oluştuğu görülmektedir. \%73.0'ı lisans mezunu, \%67.7'si kadroludur. Hemşirelerin $\% 41.6$ 'sı 5 yıl ve altında meslekte çalışma süresine sahip olup, $\% 41.6$ 'sı dahili kliniklerde, \%79.2'si 8 saatlik vardiyalar şeklinde çalışmaktadır. Hemşirelerin \%77,9'u haftalık 41 saat ve üzerinde çalışmakta, \%34.1'i günlük ortalama 21 ve üzeri sayıda hastaya bakım vermektedir. Katılımcıların \%65.9'u mesleğini isteyerek seçtiğini, \%51.8'i mesleğinden memnun olduğunu belirtmiş olup, $\% 76.5^{\prime}$ inin mesleki dernek üyeliği bulunmamaktadır (Tablo 2 ).

Tablo 2. Hemşirelerin Bazı Demografik ve Çalışma Özelliklerine Göre Dağılımı ( $n=226)$

\begin{tabular}{|c|c|c|}
\hline Tanıtıcı Özellik & Sayı & $\%$ \\
\hline \multicolumn{3}{|l|}{ Yaş } \\
\hline $19-25$ yaş & 54 & 23.9 \\
\hline $26-32$ yaş & 108 & 47.8 \\
\hline 33-39 yaş & 40 & 17.7 \\
\hline 40 yaş ve üzeri & 24 & 10.6 \\
\hline \multicolumn{3}{|l|}{ Cinsiyet } \\
\hline Kadın & 176 & 77.9 \\
\hline Erkek & 50 & 22.1 \\
\hline \multicolumn{3}{|l|}{ Medeni durum } \\
\hline Evli & 95 & 42.0 \\
\hline Bekar & 131 & 58.0 \\
\hline \multicolumn{3}{|l|}{ Eğitim durumu } \\
\hline Lise & 27 & 11.9 \\
\hline Önlisans & 16 & 67.1 \\
\hline Lisans & 165 & 73.0 \\
\hline Yükseklisans ve üzeri & 18 & 8.0 \\
\hline \multicolumn{3}{|c|}{ Meslekte toplam çalışma süresi } \\
\hline 5 yıl ve altı & 94 & 41.6 \\
\hline $6-10 \mathrm{yıl}$ & 74 & 32.7 \\
\hline $11-15$ yıl & 24 & 10.6 \\
\hline 16 yıl ve üzeri & 34 & 15.0 \\
\hline \multicolumn{3}{|l|}{ Kadro durumu } \\
\hline Kadrolu & 153 & 67.7 \\
\hline Sözleşmeli & 73 & 32.3 \\
\hline \multicolumn{3}{|l|}{ Çalışılan klinik } \\
\hline Dahili klinik & 94 & 41.6 \\
\hline Cerrahi klinik & 64 & 28.3 \\
\hline Acil servis & 16 & 7.1 \\
\hline Yoğun Bakım & 52 & 23.0 \\
\hline
\end{tabular}


Tablo 2. Hemşirelerin Bazı Demografik ve Çalışma Özelliklerine Göre Dağılımı ( $n=226$ )

\begin{tabular}{|c|c|c|}
\hline Tanıtıcı özellik & Sayı & $\%$ \\
\hline \multicolumn{3}{|l|}{ Klinikteki görevi } \\
\hline Klinik sorumlusu & 34 & 15.0 \\
\hline Klinik hemşiresi & 192 & 85.0 \\
\hline \multicolumn{3}{|l|}{ Çalışma sistemi } \\
\hline Gündüz mesai & 47 & 20.8 \\
\hline Vardiya & 179 & 79.2 \\
\hline \multicolumn{3}{|l|}{ Haftalık çalışma süresi } \\
\hline 40 saat & 50 & 22.1 \\
\hline 41 saat ve üzeri & 176 & 77.9 \\
\hline \multicolumn{3}{|c|}{ Günlük bakım verilen hasta sayısı } \\
\hline 1-10 hasta & 75 & 33.2 \\
\hline 11-20 hasta & 74 & 32.7 \\
\hline 21 ve üzeri sayıda hasta & 77 & 34.1 \\
\hline \multicolumn{3}{|c|}{ Mesleği isteyerek seçme durumu } \\
\hline Evet & 149 & 65.9 \\
\hline Hayır & 77 & 34.1 \\
\hline \multicolumn{3}{|c|}{ Mesleğinden memnun olma durumu } \\
\hline Memnun & 117 & 51.8 \\
\hline Memnun değil & 109 & 48.2 \\
\hline \multicolumn{3}{|l|}{ Mesleki dernek üyeliği } \\
\hline Var & 53 & 23.5 \\
\hline Yok & 173 & 76.5 \\
\hline Toplam & 226 & 100.0 \\
\hline
\end{tabular}

Tablo 3'de araştırma kapsamına alınan hemşirelerin bakım planı kullanımına ilişkin bilgilerini yeterli bulma durumları ve bilgi kaynaklarına göre dağılımı sunulmuştur. Tabloda, sağlık profesyonellerinin \%65.9'unun bakım planı kullanımına ilişkin bilgilerini yeterli bulduğu görülmektedir. Hemşirelerin klinik bakım planı kullanımına ilişkin bilgi edindikleri kaynaklar mezuniyet öncesi örgün eğitim programları (\%88.1), klinik sorumlusu (\%14.2) ve meslektaşlar (\%5.8) olarak sıralanmaktadır.

Katılımcıların \%70.8'i çalıştıkları kliniklerde bakım planlarının etkin kullanılmadığını belirtmiştir. Katılımcıların $(n=226)$ bakım planlarının etkin kullanımına engel olduğunu düşündükleri durumlar arasında ilk üç sırada; iş yükünün fazlalığı (\%66.8), sağlık personelinin sayısal azlığı (\%66.4) ve zaman yetersizliğinin (\%63.3) geldiği görülmektedir (Tablo 4).
Tablo 3. Hemşirelerin Bakım Planı Kullanımına İlişkin Teorik Bilgilerini Yeterli Bulma Durumları ve Bilgi Kaynaklarına Göre Dağılımı ( $n=226)$

\begin{tabular}{|l|c|r|}
\hline \multicolumn{2}{|l|}{ Sayı } & $\%$ \\
\hline Teorik Bilgiyi Yeterli Bulma Durumu & 149 & 65.9 \\
\hline Yeterli & 77 & 34.1 \\
\hline Yetersiz & $\mathbf{2 2 6}$ & $\mathbf{1 0 0 . 0}$ \\
\hline Toplam & 199 & 88.1 \\
\hline Bilgi Kaynakları* & 32 & 14.2 \\
\hline $\begin{array}{l}\text { Mezuniyet öncesi örgün eğitim } \\
\text { programı }\end{array}$ & 13 & 5.8 \\
\hline Klinik sorumlusu & & \\
\hline Meslektaş & & \\
\hline
\end{tabular}

*Birden fazla yanıt olduğu için yüzdeler $n$ üzerinden alınmıştır.

Tablo 4. Hemşirelerin Çalıştıkları Kliniklerde Bakım Planını Etkin Kullanma Durumları ve Bakım Planı Kullanımına Yönelik Engellerinin Dağılımı ( $n=226)$

\begin{tabular}{|l|c|c|}
\hline & Sayı & \% \\
\hline Evet & 66 & 29.2 \\
\hline Hayır & 160 & 70.8 \\
\hline Toplam & $\mathbf{2 2 6}$ & $\mathbf{1 0 0 . 0}$ \\
\hline Engeller * & 151 & 66.8 \\
\hline İ̧ yükünün fazla olması & 150 & 66.4 \\
\hline $\begin{array}{l}\text { Sağlık personelinin } \\
\text { sayısal azlığı }\end{array}$ & 143 & 63.3 \\
\hline \begin{tabular}{l} 
Zaman yetersizliği \\
\hline $\begin{array}{l}\text { Hasta sayısının fazla } \\
\text { olması }\end{array}$
\end{tabular} & 140 & 61.9 \\
\hline $\begin{array}{l}\text { İş merkezli çalışma } \\
\text { Bilgisayar tabanlı veri } \\
\text { toplama ve bakım planı } \\
\text { sisteminin olmaması }\end{array}$ & 95 & 42.3 \\
\hline $\begin{array}{l}\text { Bakım planının iş yükü } \\
\text { olarak görme }\end{array}$ & 91 & 42.0 \\
\hline Malzeme yetersizliği & 80 & 40 \\
\hline Bilgi eksikliği & 38 & 35.4 \\
\hline
\end{tabular}

* Birden fazla yanıt olduğu için yüzdeler $\mathrm{n}$ üzerinden alınmıştır.

Araştırma kapsamına alınan hemşirelerin önerileri arasında ilk sırada sağlık personeli sayısının artırıması (\%96.9) yer almaktadır. Bu öneriyi bakım planı kullanımına ilişkin periyodik hizmet içi eğitimlerin verilmesi (\%94.2) ve hasta bakımı kaydında kullanılan form sayısının azaltılması (bası yarası, düşme riski formları vb.) (\%93.4) gibi öneriler izlemektedir (Tablo 5). 
Tablo 5. Hemşirelerin Bakım Planı Kullanımının İyileştirilmesine ilişkin Çözüm Önerilerinin Dağılımı (n=226)

\begin{tabular}{|c|c|c|c|c|}
\hline \multirow[b]{2}{*}{ Öneriler } & \multicolumn{2}{|c|}{ Katılıyorum } & \multicolumn{2}{|c|}{ Katılmıyorum } \\
\hline & Sayı & $\%$ & Sayı & $\%$ \\
\hline \multicolumn{5}{|l|}{ Kurumsal Öneriler } \\
\hline Hemşire sayısının artırılması & 219 & 96.9 & 7 & 3.1 \\
\hline Hasta bakımı kaydında kullanılan form sayısının azaltılması (Bası yarası, düşme riski. gibi formların kaldırılması) & 211 & 93.4 & 15 & 6.6 \\
\hline Bakım planlarının bilgisayar tabanlı kayıt sistemi ile yeniden yapılandırılması için fiziki koşulların hazırlanması & 205 & 90.7 & 21 & 9.3 \\
\hline Hasta kabul formlarında bulunan ama kullanılmayan bazı alanların kaldırılması & 192 & 85.0 & 34 & 15.0 \\
\hline $\begin{array}{l}\text { Bası yarası ve düşme riski ile ilgili formların risk derecelendirmeye yönelik olarak ön yüzünde bulunan alanların } \\
\text { bulunması ancak hemşirelik bakımına yönelik diğer kayıtlarının bakım planından takip edilmesi }\end{array}$ & 202 & 89.4 & 24 & 10.6 \\
\hline Kurumda bakım planları için standart dosyalama sisteminin olması & 202 & 89.4 & 24 & 10.6 \\
\hline Bakım planı uygulamasının performans ödemelerine yansıtılması & 203 & 89.8 & 23 & 10.2 \\
\hline Çalışan motivasyonunun artırılması & 199 & 88.1 & 27 & 11.9 \\
\hline $\begin{array}{l}\text { Gözlem notlarının ya da bakım planlarının kayıtta kullanılması } \\
\text { (Hemşire gözlemlerin arka sayfasında bulunan not bölümünün kaldırılması ve hemşire vardiya değişimlerinde } \\
\text { teslimlerin bakım planı kayıtları üzerinden verilmesi) }\end{array}$ & 192 & 85.0 & 34 & 15.0 \\
\hline Hasta eğitimleri ile ilgili kayıtların bakım planından yapılması & 193 & 85.4 & 33 & 14.6 \\
\hline Hastane yönetimi tarafından fiziki koşulların oluşturulması (Gerekli malzeme, araç- gereç desteğinin sağlanması) & 168 & 74.3 & 58 & 25.7 \\
\hline \multicolumn{5}{|l|}{ Eğitim ile İlgili Öneriler } \\
\hline Bakım planı kullanımına ilişkin periyodik hizmet içi eğitimler verilmesi & 213 & 94.2 & 13 & 5.8 \\
\hline \multicolumn{5}{|l|}{ Bakım Planı Formatı ile ilgili Öneriler } \\
\hline $\begin{array}{l}\text { Kliniklere özgü sık kullanılan tanıların belirlenip bir formda yer alacak şekilde birleştirilmesi } \\
\text { (Mevcut bakım planı formatının bu şekilde revize edilmesi) }\end{array}$ & 205 & 90.7 & 21 & 3.3 \\
\hline $\begin{array}{l}\text { Tanılara yönelik değerlendirme kriterlerinin bakım planı formlarına eklenmesi ve çentik atılabilir şekilde } \\
\text { düzenlenmesi }\end{array}$ & 205 & 90.7 & 21 & 9.3 \\
\hline $\begin{array}{l}\text { Tanı ve uygulamaların ilgili alanda uzman kişilerle çalışılarak artırılması, kliniklere özgü ve bireyselleştirilmiş } \\
\text { formata dönüştürülmesi }\end{array}$ & 203 & 89.8 & 23 & 10.2 \\
\hline Klinik bilgisayarlarında hastaların tıbbi tanısına yönelik konulabilecek tanıların ayrı klasörler altında toplanması & 190 & 84.1 & 36 & 15.9 \\
\hline Mevcut formda hemşirenin imza atacağı bir alan oluşturulması & 177 & 78.3 & 49 & 21.7 \\
\hline Bakım planında bulunan değerlendirme alanının genişletilmesi & 154 & 68.1 & 72 & 31.9 \\
\hline Bakım planı formlarına verilerin kayıt edilebilmesi için alan eklenmesi & 172 & 76.1 & 54 & 23.9 \\
\hline
\end{tabular}

* Birden fazla yanıt olduğu için yüzdeler $n$ üzerinden alınmıştır. 


\section{TARTIŞMA}

Bir üniversite hastanesinde hemşirelik süreci doğrultusunda oluşturulan bakım planlarının uygulanmasına yönelik güçlüklerin tespit edilmesi ve mevcut uygulamanın iyileştirilmesine yönelik görüş ve önerilerin belirlenmesi amacıyla yapılan çalışmada, odak grup görüşmesine katılan hemşirelerin, genel olarak hemşirelik bakım planı ile çalışmayı yararlı bulduğu, ancak bakım planlarını birçok faktörün etkisiyle yeterince etkin kullanamadıkları sonucuna ulaşılmıştır. Çalışmamızın nitel verileri kapsamında katılımcılar tarafından hemşirelik bakım planı uygulamasına yönelik yaşadıkları güçlükler; kliniklerde hemşire sayısının yetersiz olması, bakım verilen hasta sayısının fazla olması, zaman yetersizliği, bakım planı ile çalışmaya başlamadan önce tüm uygulayıcıların kapsamlı ve sistematik bir eğitim sürecinden geçmemesi, kağıt çıktısı alınması nedeniyle dosyalama ve kayıt sırasında yaşanan zorluklar ve iş yükü olarak görülmesi şeklinde sıralanmıştır. Çalışmamızda bakım planının uygulanmasına yönelik tespit edilen güçlükler, literatürde yer alan çok sayıda çalışma ile benzerlik göstermektedir ${ }^{10-20}$. Hemşireler tarafından ifade edilen bu güçlükler nedeniyle kurumda hemşirelik sürecinin etkin olarak kullanamadığı sonucuna varılmıştır. Bu bağlamda profesyonel bakım hizmetinde hemşirelik sürecinin etkin kullanımı için olumsuz kurumsal faktörlerin ortadan kaldırılması, hemşirelik hizmetleri yöneticilerinin hemşirelik sürecinin gerekliliği, önemi hakkında sağıık profesyonellerini yönlendirmesi ve onlara uygulamada danışmanlık etmelerinin önemli olduğu düşünülmektedir.

Araştırmanın nicel boyutunda elde edilen verilere göre, araştırmamız kapsamında yer alan hemşirelerin yarıdan fazlası bakım planı hazırlama ile ilgili sahip oldukları teorik bilgiyi yeterli bulduğunu ve bu bilgiyi mezuniyet öncesi örgün eğitim programı ile kazandığını ifade etmiştir (Tablo 3). Örgün eğitim döneminde alınan bilgilerin, okul hastane iş birliği sağlanarak çalışma yaşamı içinde hizmet içi eğitimlerle güncellenmesi önemlidir. Teorik bilgi kaynağı olarak mezuniyet öncesi örgün eğitim programlarının gösterilmesi ise beklenen bir sonuçtur. Nitekim hemşirelik eğitiminin ilk yılından itibaren bakım planı kullanarak çalışma becerisinin geliştirilmesi geleceğin profesyonel hemşirelerinin yetiştirilmesinde önemsenen bir durumdur. Bu bağlamda hemşirelik eğitiminde bakım planı uygulamasının vaka çalışmaları ile somut hale getirilmesi, tüm mesleki derslerde ortak bir dil kullanılarak verilerin yorumlanması ve problemlerin tanılanması, bakım planı uygulamasının ödev ve not verme aracı olarak değil, bakımın bilimsel temellere dayandırılmasında önemli bir araç olduğunun öğrenciye fark ettirilmesinde eğitimcilere büyük sorumlulukların düştüğü söylenebilir.

Bakım planı ile çalışmanın bakımın niteliğine katkı sağladığı bilinmesine rağmen, klinikte etkin kullanımına engel oluşturan birçok durum yaşanmaktadır. Bu araştırmada, katılımcıların yaklaşık 2/3'ü çalıştıkları kliniklerde bakım planının etkin kullanılmadığını düşünmektedir (Tablo 3). Katılımcıların bakım planlarının etkin kullanımına engel olduğunu düşündükleri durumlar arasında ilk dört sırada sırasıyla; iş yükünün fazla olması, sağlık personelinin sayısal azlığı, zaman yetersizliği ve hasta sayısının fazla olmasının geldiği belirlenmiştir (Tablo 3 ). Çalışmamızda katılımcılar tarafından bakım planının uygulanmasına engel olan diğer durumlar şu şekilde sıralanmıştır: Bilgisayar tabanlı veri toplama ve bakım planı sisteminin olmaması, iş merkezli çalışma, bakım planının iş yükü olarak görülmesi, malzeme yetersizliği ve bilgi eksikliği (Tablo 3 ). Literatürde yer alan ulusal ve uluslararası çalışmalarda araştırma bulgularımızla benzer şekilde yüksek oranda iş yükü, hasta sayısının fazla olması, sistem/alt yapı eksikliği, eleman yetersizliği, zaman yetersizliği, yeterli bilgi ve donanıma sahip olmama, bakım planı ile çalışmayı iş yükü olarak görmenin bakım planı kullanımına engel olan en önemli ve öncelikli engeller olduğu bildirilmiştir ${ }^{10-20}$.

Çalışmamızda sağlık profesyonellerinin neredeyse tamamının uygulanmakta olan bakım planının iyileştirilmesine ilişkin çözüm önerileri arasında ilk sırada sağlık personeli sayısının artırılması gelmektedir (Tablo 5). Uluslararası bir çalışmada ancak yeterli sayıda personel ile etkili, verimli ve sistematik hemşirelik uygulamalarının gerçekleştirilebileceği, bunun için sağlık bakanlığının harekete geçmesi gerektiğine vurgu yapılmıştır ${ }^{13}$.Çalışmamızda yer alan katılımcılar bakım planının daha etkin hale getirilmesi için; bakım planının bilimsel dayanaklar ve üst yönetimin desteği ile yeniden yapılandırılması ve bireyselleştirilmiş bakım planı formatına dönüştürülmesi, bilgisayar tabanlı kayıt sistemi ve bakım planı uygulamasına geçilmesi, tüm bakım kayıtlarının bakım planı kapsamında yer alması, farklı klinik ve birimlerin kendilerine özel tanılar koyabilmesi ve bu konuda alanında uzman kişilerden destek alınması, uygulamalarda ortaklaşmak adına tüm hemşirelerin bakım planı eğitimlerinin güncellenmesi ve mevcut basılı bakım planı formunda veri kaydı, bakımın değerlendirmesi ve imza için yeterli/ uygun alanların bulunması önerilerinde bulunmuştur (Tablo 5). Bu bağlamda hem ulusal ${ }^{10,16-20}$ hem de uluslararası ${ }^{11-15}$ literatürde bakım planının iyileştirilmesine yönelik benzer önerilerin yer aldığı görülmüştür. Bununla birlikte birçok klinikte bakım girişimleri ilaç verme, hasta takiplerini yapma ve bireyin yalnızca biyolojik gereksinimleri üzerine yoğunlaşmakta, profesyonel bilgi eksikliği, süreci tanımama, zaman eksikliği, aşırı iş yükü ve bürokratik engeller gibi etkenler nedeniyle bakım planları klinikte etkili biçimde uygulanamamaktadır. Veriler yukarıda belirtilen birçok durumun kliniklerde bakım planı ile çalışmak isteyen donanımlı ve istekli profesyoneller için engel oluşturduğu şeklinde yorumlanabilir.

Literatür ${ }^{14,19,22,23}$ ve araştırmamızda yer alan katılımcıların önerileri doğrultusunda hastanede kullanılmakta olan mevcut kâğıt tabanlı bakım planı formatının bilgisayar tabanlı bakım planı formatına dönüştürülmesinin kuşkusuz çalışanlar için önemli bir revizyon olacağı, bu düzenleme ile birlikte kliniklere özgü bireyselleştirilmiş bakımın gerçekleştirilebileceği öngörülmektedir. Aynı zamanda bu revizyon ile hemşirelik ve tıbbi kayıt sistemi arasında entegrasyon sağlanabilecek ve hemşirelik bakımı daha görünür hale gelebilecektir. Profesyonel yaşamdaki başarıda 
hemşirelerin yeni yaklaşım ve uygulamalara uyumlandırılmasının da önemli faktör olduğu söylenebilir. $\mathrm{Bu}$ bağlamda periyodik aralıklarla alanın uzmanları tarafından gerçekleştirilecek hizmet içi eğitim programlarının hemşirelik sürecinin önemi ve gereğine yönelik farkındalık, duyarlıık ve motivasyonun artışına katkı sağlayacağı düşünülmektedir.

\section{SONUÇ ve ÖNERILER}

Araştırmadan elde edilen nitel ve nicel veriler doğrultusunda çalışmanın uygulandığı hastanede hemşirelerin hemşirelik bakım planlarını etkin olarak kullanamadıkları ve buna birçok faktörün neden olduğu tespit edilmiştir. Etkili, hedefe dönük ve bireyselleştirilmiş bakım planının hayata geçirilmesini sağlamada; standardize edilmiş formlar yerine kliniklere özel, kolay uygulanabilir bakım planı formlarının geliştirilmesi, kliniklerde hastaya özgü doldurulması gereken formların bakım planı ile bütünleştirilmesini sağlayacak çalışmaların yapılması, eksiksiz ve hatasız kayıt olarak kayıt yapabilmeye aynı zamanda kliniklere özel bireyselleştirilmiş bakım planlarının yapılabilmesine olanak sağlayan bilgisayar tabanlı kayıt sisteminin geliştirilmesi ve kullanılabilmesi önerilmiştir.

Etik Kurul Onayı: Araştırmanın uygulanabilmesi için Cumhuriyet Üniversitesi Girişimsel Olmayan Klinik Araştırmalar Etik Kurulu'ndan onay alınmıştır (Karar numarası: 2017- 01/24).

Çıkar çatışması: Bildirilmemiştir.

Finansal destek: Alınmamıştır.

Katılımcı Onamı: Araştırmaya katılan tüm hemşirelere bilgilendirilmiş onam formu okunarak, sözlü ve yazılı izinleri alınmıştır.

Yazar katkıları

Araştırma dizaynı: ŞK, IY

Veri toplama: iY

Literatür araştırması: IY, ŞK

Makale yazımı: IY, ŞK

Teşekkür: Bu çalışmanın yürütülmesi sürecinde sağladıkları iş birliği için Cumhuriyet Üniversitesi Araştırma ve Uygulama Hastanesi yöneticileri ve idari çalışanlarına teşekkür ederiz.

Ethics Committee Approval: Approval was obtained from Cumhuriyet University Non-Invasive Clinical Research Ethics Committee (Decision number: 2017-01/24).

Conflict of Interest: Not reported.

Funding: None.

Exhibitor Consent: Verbal and written consents were obtained by reading the informed consent form of all the nurses participating in the study.

Author contributions:

Study design: ŞK, iY

Data collection: iY

Literature search: IY, ŞK

Drafting manuscript: IY, ŞK

Acknowledgement: We would like to thank the directors and administrative staff of Cumhuriyet University Research and Application Hospital for their cooperation during the execution of this study.

\section{KAYNAKLAR}

1. Birol L. Hemşirelik süreci: Hemşirelik bakımında sistematik yaklaşım. 10.bs. İzmir: Berke Ofset Matbaacılık; 2013. Bölüm 3, Hemşirelik Süreci; s.95100.

2. Delaune SC, LadnerPK. Fundamentals of Nursing Standards \& Practıce. Second Edition. Delmar Thomsan Learning; 2002. Chapter 5, Critical Thinking and the Nursing Process ; p.83.

3. World Health Organization. Lemon Learning Material on Nursing. Chapter 4: Nursing Processand Documentation [Internet]. 2009 [Erişim Tarihi: 20.05.2020]. Erişim adresi: http://www.who.int/topics/nursing/en/.

4. Kaya N. Hemşirelik süreci/ Hemşirelik tanılaması. Atabek T, Karadağ A, Editörler. Hemşirelik Esasları. İstanbul: Akademi Basın ve Yayıncılık; 2014.

5. Yıldırım B, Özkahraman Koç Ş. Eleştirel düşünmeyi hemşirelik sürecinde uygulama. Electronic Journal of Vocational College. 2013;3(3):29-35.

6. Ay FA. Temel hemşirelik: Kavramlar, ilkeler, uygulamalar. Ay FA, Editör. Hemşirelik süreci. İstanbul: Medikal Yayıncılık; 2008. s.61-72.

7. Erer MT, Akbaş M, Yıldırım G. Hemşirelik sürecinin evrimsel gelişimi hemşirelik süreci. Lokman Hekim Dergisi. 2017;7(1):1-5.

8. Resmî Gazete. Hemşirelik Kanununda Değişiklik Yapılmasına Dair Kanun [Internet]. 2007 [Erişim Tarihi: 10.09.2019]. Erişim Adresi: http://www.resmigazete.gov.tr/eskiler/2007/05/2007 0502-3.html

9. T.C. Sağlık Bakanlığı Sağlıkta Kalite, Akreditasyon ve Çalışan Hakları Dairesi Başkanlığı [Internet]. 2020 [Erişim Tarihi: 19.05.2019]. Erişim Adresi: https://kalite.saglik.gov.tr/TR,64476/sks-hastanesurum-6-yayinlandi.html

10. Zaybak A, Günay İsmailoğlu E, Özdemir H. Hemşirelerin hemşirelik süreci uygulamasında yaşadıkları güçlüklerin incelenmesi. Anadolu Hemşirelik ve Sağlık Bilimleri Dergisi. 2016;19(4):269-277.

11. Fernández-Sola C, Granero-Molina J, AguileraManrique G, Peredo-de Gonzales MH, Castro-Sánchez AM, Pérez Galdeano A. Strategies to develop the nursing process and nursing care plans in the health system in Bolivia. International Nursing Review. (in press). http://dx.doi.org/10.1111/j.14667657.2011.00884.x

12. Neco KKS, Costa RA, Feijão AR. Systematization of nursing care in health institutions in Brazil: An integrative review. Journal of Nursing UFPE on line. (in press). http://dx.doi.org/10.5205/reuol.6817-606791-ED.0901201527

13. Mahmoud MH, Bayoumy HM. Barriers and facilitators for execution of nursing process from nurses' perspective. Int J Adv Res. 2014;2(2):300-315.

14. Zamanzadeh V, Valizadeh L, Tabrizi FJ, Behshid M, Lotfi $M$. Challenges associated with the implementation of the nursing process: A systematic review. 
Iran J Nurs Midwifery Res. (in press). http://dx.doi.org/10.4103/1735-9066.161002

15. Baraki Z, Girmay F, Kidanu K, Gerensea H, Gezehgne D, Teklay $\mathrm{H}$. A cross sectional study on nursing process implementatio NANDA ssociatedf actors among nurses working in selected hospitals of Central and North West Zones, Tigray Region, Ethiopia. BMC Nurs. 2017;16:1-9

16. Fesci H, Doğan N, Pınar G. İç hastalıkları kliniklerinde çalışan hemşirelerin hasta bakımında karşılaştıkları güçlükler ve çözüm önerilerinin belirlenmesi. Atatürk Üniversitesi Hemşirelik Yüksekokulu Dergisi. 2008;11(3):40-50.

17. Andsoy II, Güngör T, Dikmen $Y$, Nabel EB. Hemşirelerin bakım planını kullanırken yaşadıkları güçlükler. Journal of Contemporary Medicine. 2013;3(1):7-11.

18. Kaplan F. Bir kamu hastanesinde çalışan hemşirelerin hemşirelik sürecine ilişkin bilgi düzeyleri ve hemşirelik sürecini kullanmalarını etkileyen faktörler. [Yüksek Lisans Tezi]. Erzurum: Atatürk Üniversitesi Sağlık Bilimleri Enstitüsü; 2016.

19. Ağaçdiken $S$, Özdelikara A, Yılmaz Güven D, Keskin Göksel A, Çakan A. Hemşirelik bakım planı ve hemşirelik sürecinin hemşirelik bakımında etkin kullanımı [Internet]. 2016 [Erişim Tarihi: 10.09.2019]. Erişim Adresi:

https://www.saglikaktuel.com/d/file/7f420beaca0d4b d3a4954470ebb7a5f8.pdf

20. Akansel N, Palloş. A. Hemşirelik öğrencilerinin bakım planı hazırlamada yaşadıkları güçlüklerin kök nedenlerinin incelenmesi. Acıbadem Üniversitesi Sağlık Bilimleri Dergisi. 2020;11(2):269-275.

21. Olmaz D, Karakurt P. Hemşirelerin Bakım Verirken Hemşirelik Sürecini Bilme ve Uygulama Durumları. Dokuz Eylül Üniversitesi Hemşirelik Fakültesi Elektronik Dergisi. 2019, 12(1): 3-14

22. Dikmen $Y, A k B$, Yorgun S. Teorikten pratiğe: Bilgisayar destekli hemşirelik süreci uygulaması. J hum rhythm. 2015;1(4):162-167.

23. Ay FA. Uluslararası elektronik hasta kayıt sistemleri, hemşirelik uygulamaları ve bilgisayar ilişkisi. Gülhane Tıp Dergisi.2009;51(2):131-136. 